\title{
WH-HEADLINES IN GERMAN. WHAT THEY COMMUNICATE AND WHETHER THEY OPTIMIZE RELEVANCE
}

\author{
Rita Finkbeiner \\ Johannes Gutenberg University Mainz \\ finkbeiner@uni-mainz.de
}

\begin{abstract}
This paper is about a particular wh-clause type in German that is restricted in its usage to headlines. This clause type, exemplified by the newspaper headline Wie Kassen an Kranken verdienen ('How health insurance companies make money on sick people'), formally looks like an embedded interrogative wh-clause, but is used independently as a headline with a particular, non-questioning illocution. The main question raised in this paper is how the illocution of wh-headlines is to be specified, and how it can be accounted for. The paper suggests an analysis of wh-headlines as both backward- and forward-referring means that are very well-suited to fulfill the two main functions of headlines, namely, to arouse the reader's interest and to direct the reader's attention to the subsequent text. The complex illocution of wh-headlines is derived from an interaction between formal properties of the clause type and contextual restrictions. In the final section of the paper, the more general question is raised whether wh-headlines can be regarded as relevance optimizers, as has been suggested for other kinds of newspaper headlines. This question is discussed based on a comparison between whheadlines, assertive headlines and click baits. ${ }^{*}$
\end{abstract}

\section{Keywords}

illocution, newspaper headline, quotation, relevance, sentence type, syntaxpragmatics interface, wh-headline 


\section{Introduction}

In German newspapers, one frequently comes across verb-final wh-clauses as headlines, e.g. 1-3. I will refer to them, henceforth, as wh-headlines.

(1) Wie Kassen an Kranken verdienen

(Süddeutsche Zeitung, 20 June 2017)

how health insurance companies on sick people make money 'How health insurance companies make money on sick people' Warum die Hungersnot uns angeht

(Frankfurter Rundschau, 26 February 2017)

why the hunger crisis us concerns

'Why the hunger crisis concerns us'

Was Frauen für ihren Kinderwunsch tun

(Frankfurter Rundschau, 24 March 2017)

what women for their wish to have children do

'What women do for their wish to have children'

Wh-headlines share the formal features of German dependent interrogative clauses, as exemplified in 4 , which are embedded under a questioning matrix verb. They display a wh-element in left-most position and the finite verb in clause-final position.

(4) (Heinz fragt,) warum die Hungersnot uns angeht.

(Heinz asks) why the hunger crisis us concerns.

'(Heinz asks) why the hunger crisis concerns us'

However, it is obvious that 1-3 are not syntactically dependent on a matrix verb, but are used as independent utterances. The default speech act that is performed with the utterance of an independent interrogative clause is a question. Characteristic properties of questions, as held in standard approaches to speech acts (Searle 1969), include that there is a knowledge gap on the side of the speaker, that the speaker believes that the addressee knows the answer, and that the speaker wants the addressee to provide the answer. However, in the newspaper context of $1-3$, we cannot plausibly assume that there is a knowledge gap on the side of the author, nor that the author attempts to make the reader provide the answer. Rather, there seem to be other, specific communicative effects that are reached by a wh-headline.

Comprehensive and systematic studies on the communicative effects of wh-headlines are lacking, though. Despite their pervasive use in the media, which seems to be intimately connected with their specific functional potential, wh-headlines have been largely neglected in previous research on the syntax-pragmatics interface, text linguistics, stylistics, and media studies. All one can find are some sparse remarks on wh-headlines in older 
monographs on headlines, such as Sandig (1979) and Mårdh (1980), and as well as in some earlier work on German verb-final clause types (e.g. Weuster 1983, Oppenrieder 1989). This is all the more remarkable since wh-headlines are pervasive not only in German-speaking newspapers, but also in other discourse types such as chapter headings in fiction and non-fiction, book titles, or film titles. Furthermore, wh-headlines can be found in other European languages as well, cf., e.g., 5-8.

(5) English

Why our Soccer stars are in trouble (cf. Mårdh 1980: 129)

(6) Swedish

Hur man botar en fanatiker ${ }^{1}$

'How one cures a fanatic'

(7) Danish

Hvad vi ved om udsatte unge ${ }^{2}$

'What we know about vulnerable youth'

(8) French

Comment les riches échappent à l'impot (cf. Held 2005: 189) ${ }^{3}$

'How the rich elude taxes'

While these examples are not verb-final - this being a feature specific to German embedded clauses -, they nevertheless display the respective language's subordinate syntax while being used in main clause fashion. Compare the following contrasts, which indicate that the wh-headline syntactically patterns with the subordinate clause, not the main clause.

English

(9) a. Why our Soccer stars are in trouble (wh-headline)

b. (John asks) why our Soccer stars are in trouble. (subordinate clause)

(10) Why are our Soccer stars in trouble? (main clause)

Swedish

(11) a. Hur man botar en fanatiker (wh-headline)

b. (Pelle frågar) hur man botar en fanatiker. (subordinate clause)

Hur botar man en fanatiker? (main clause)

Danish

a. Hvad vi ved om udsatte unge (wh-headline)

b. (Jesper spørger) hvad vi ved om udsatte unge. (subordinate clause)

Hvad ved vi om udsatte unge? (main clause) 
French

a. Comment les riches échappent à l'impot (wh-headline)

b. (Laurent demande) comment les riches échappent à l'impot. (subordinate clause)

Comment est-ce que les riches échappent à l'impot? (main clause)

As to the communicative effects of canonical questions in headlines, there are a number of studies, mainly from the perspective of social psychology and behavioral sciences (e.g. Moore et al. 2012, Lai \& Farbrot 2014). It has been claimed in these studies that questions lend themselves to the use as headlines because of their ability to initiate cognitive processes and to generate attention and curiosity (Lai \& Farbrot 2014: 290). However, a linguistic explanation of the alleged suitability of questions as headlines is lacking. After all, questions are, in the default case, requests for answers, whereas headlines, in the default case, do not ask the readers for answers.

In this paper, I will argue, with respect to wh-headlines in German newspapers, that the syntactic properties of the clause type play an important role in the determination of its functional potential. It will be shown that because of their having the syntax of a subordinate clause, wh-headlines are especially apt to fulfil the main functions of headlines: to catch the reader's interest, and to direct her attention to the subsequent text.

Previous studies on the pragmatic functions of headlines have argued that headlines function as relevance-optimizers for readers (Dor 2003, Ifantidou 2009). As Dor (2003: 705) points out, as a short and simple text, a headline optimizes the relevance of the story for the reader by minimizing processing effort while making sure that a sufficient amount of contextual effects are deducible within the most appropriate context possible. Against this backdrop, a further issue this paper raises is whether wh-headlines can be regarded as relevance optimizers. It will be argued that as a forward-referring expression, a wh-headline is always intimately connected to its subsequent text and can reach optimal relevance for the reader only if the reader also reads (at least part of) the text.

The structure of the paper is as follows. In section 2, I will discuss a number of previous suggestions as to the communicative potential of wh-headlines, arguing that the emerging picture is rather heterogeneous and inconsistent. Against this backdrop, I will present my own hypothesis as to the illocutionary force of wh-headlines, which states that wh-headlines are meta-representative speech acts that are both quotational, i.e. backward-referring to a (virtual) reader question, and forward-referring to the subsequent text. In section 3, I outline the basic assumptions of compositional theories on the interrelation between clause types and speech acts and discuss the question whether the ability of wh-headlines to carry illocutionary potential can be accounted for within these approaches. It will turn out that the illocutionary potential of 
wh-headlines cannot be derived from formal properties alone. In section 4, I pursue, in more detail, the question why wh-headlines communicate what they communicate. I argue that their illocutionary function can be derived from an interaction between formal properties of the clause type and contextual restrictions on the headline. In section 5, I widen the perspective, turning to the question whether wh-headlines optimize relevance for the reader. I discuss this question against the backdrop of a comparison with click baits and assertive headlines. Section 6 summarizes the paper.

\section{What wh-headlines communicate}

In a number of earlier work on German verb-final clause types, wh-headlines are recognized as a special wh-clause type that can be found in headlines (e.g., Stojanova-Jovčeva 1980, Weuster 1983, Winkler 1989, Oppenrieder 1989). However, to date, wh-headlines have not been subject to systematic theoretical or empirical investigation. As to the question which illocutionary function wh-headlines fulfil, various tentative answers have been suggested. In her survey on German verb-final clause types, Weuster (1983: 54) suggests that wh-headlines are "verweisende Ergänzungsfragen ohne Frageillokution" ('referring wh-questions without question illocution'). Altmann (1987: 28), who mentions wh-headlines in passing, claims that speakers do not have clear intuitions about the function of wh-headlines. Luuko-Vinchenzo (1988:118), in a monograph on the functions of interrogative clauses in German and Finnish, assigns to wh-headlines "ein assertives oder direktives Illokutionspotential" ('an assertive or directive illocutionary potential'), and Oppenrieder (1989: 215) characterizes wh-headlines functionally as having "eine spezialisierte assertive Funktion der Ankündigung" ('a specialized assertive function of an announcement'). In a recent article on sentence mood in German, Pafel (2016: 412) subsumes wh-headlines under the declarative mood. Taken together, it becomes clear that the various authors have diverging opinions as to the illocutionary functions of wh-headlines.

While I would agree with Weuster (1983) and Oppenrieder (1989) that one function of wh-headlines is to direct the reader to the accompanying text, this function must be spelled out in more detail. Weuster's rather unfortunate terminology ("wh-questions without question illocution") is misleading in this connection, and Oppenrieder's "announcement" function is not specific enough. Headlines are textual building blocks that are part of a specific configuration of headline and text. If they "point" to a text, or "announce" a text, this must be some kind of meta-representational function. However, a prototypical announcement, such as, e.g., the utterance Me and Agnetha are going to marry, with which the speaker announces a marriage, is not meta-representational. Turning to Altmann's claim that readers do not have clear intuitions about the function of wh-headlines, this claim is not empirically substantiated. While readers may well have clear intuitions about 
the functions of wh-headlines, it seems that wh-headlines do not fit properly into Altmann's system of sentence moods in German. So the task would be to adjust the system, rather than exclude wh-headlines because of an alleged lack of speaker intuitions. Regarding Luuko-Vinchenzo's alternative "assertive or directive", this is based on the intuition that wh-headlines may be paraphrased by assertions such as Here you can read how health insurance companies make money on sick people, or by directives such as Inform yourself here (about) how health insurance companies make money on sick people. However, it remains unclear in Luuko-Vinchenzo's account how this alternative is to be explicated. Is this a choice the reader has? Are some wh-headlines assertive, while others are directive? Or do wh-headlines fulfil both functions simultaneously? Finally, Pafel's move to subsume wh-headlines under the declarative mood is not unproblematic either. Within Pafel's system of intentional moods, the declarative is represented as "S intends to inform A that p". However, it is not fully correct to say that by uttering a wh-headline, an author intends to inform a reader that $\mathrm{p}$. Rather, by uttering the subsequent text, the author intends to inform the reader that $\mathrm{p}$.

In what follows, I would like to outline an account of the illocutionary function of wh-headlines that is informed by analyses of a sample of more than 3.000 wh-headlines that were collected from newspaper corpora of the DeReKo (Deutsches Referenzkorpus). ${ }^{4}$ This account is a refinement of the approach taken by Finkbeiner (2018). After presenting what I take to be the main communicative effects of wh-headlines, I will argue that these effects result from an interaction of the specific formal properties of the clause type and specific contextual requirements of the headline format. Before I turn to the illocutionary functions of wh-headlines, a methodological remark is in order. The functional analyses that are presented below - as, arguably, all kinds of functional analyses - are to some extent subjective. While the argumentation is based on a large sample of attested examples of wh-headlines, I also rely on linguistic intuition when explicating their illocutionary functions. This is due to the fact that the headline corpus is of limited expressivity when it comes to the question of headline functions. Eventually, headline functions must be investigated by psycholinguistic experimentation, something which I must leave for further work.

Approaching the question which illocutionary function wh-headlines fulfill, let us take the wh-headline 1 , here repeated as 17 , as an illustrative example.

Wie Kassen an Kranken verdienen

'How health insurance companies make money on sick people'

The headline 17 is taken from a news article on how health insurance companies manipulate doctors to falsely diagnose severe illnesses, e.g., a 
depression instead of a temporary blues, in order to gain extra money from the German Health Fonds (Gesundheitsfonds). Figure 1 depicts the headline in the context of the news article.

\section{Wie Kassen an Kranken verdienen}

Versicherungen drängen Ärzte zu Falschdiagnosen, kritisieren Experten

Berlin - Eine Depression ist wirklich keine schöne Sache. Wenn ein Arzt diese Diagnose stellt, gibt es seit einigen Jahren trotz dem immer eine Institution, für die das eine gute Nachricht ist. Es ist die Krankenkasse des Patienten. Denn sobald Mediziner eine von 80 ausgewählten Krankheiten diagnostizieren, die auf einer Liste des Bundesversicherungsamts stehen, darunter eben Depressionen, bekommen die Kassen Extrageld aus dem deutschen Gesundheitsfonds. Diesen Mechanismus hat die Politik vor acht Jahren eingeführt, um diejenigen Kassen zu unterstützen, die besonders viele kranke Menschen versichern. Er heißt Risikostrukturausgleich. Damals ging es um Gerechtigkeit.

Bloß: Gerecht geht es bei diesem Ausgleich schon lange nicht mehr zu, dafür gibt es immer mehr Hinweise. Weil es sich für Kassen lohnt, wenn ihre Versicherten an schweren Krankheiten leiden, haben sie offenbar damit begonnen, Ärzte zu lukrativen Diagnosen zu überreden. Im April

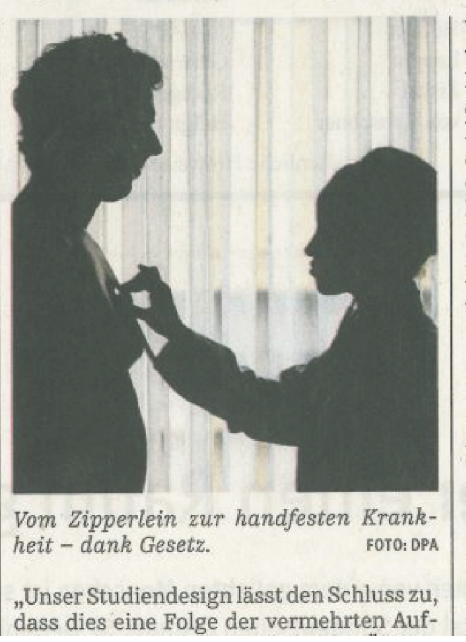

Figure 1. Headline "Wie Kassen an Kranken verdienen" in the context of the news article (excerpt), Süddeutsche Zeitung, 20 June 2017.

What are the specific communicative effects of a 17? To begin with, 17 suggests that the accompanying text will tell the reader how health insurance companies make money on sick people. Importantly, while 17 does contain a knowledge gap, marked by the wh-phrase wie ('how'), the utterance of 17 does not count as a request for information, in the sense of Searle's (1969) essential condition. Rather, the illocutionary point of 17 is that of an assertion that the text will provide information related to the wh-gap. However, this is not all there is to say about the illocutionary force of wh-headlines. As I will argue in more detail below, 17 also suggests that at some point in previous discourse, the question has been asked how insurance companies make money on sick people. Thus, while the utterance of 17 itself is not a question, it is interpreted as taking up, or as backward-referring to a previously raised question. In this respect, as well as to its subordinate syntax, it bears resemblance to echo questions as discussed by Nielsen (2020, this issue), cf. 18 .

(18) What the reason is? [continued by: The reason is that we have been insulted by the attitude of Russia; example taken from Nielsen, this issue] 
According to Nielsen, 18 "is characterized by the fact that the sender is not responsible for the speech act of asking, but rather for the speech act of reproducing an already stated question". However, 18 still is a question, albeit not a wh-question, but a yes/no question: In uttering 18, the speaker asks whether it is the case that the addressee wants to know what the reason is, thereby intending to provide the reason in the subsequent speech act. By contrast, a wh-headline such as What the reason is (with falling intonation) neither is a wh-question nor a yes/no question. While it also refers to an already stated question, it does not ask whether the addressee wants to know what the reason is, but it asserts that the subsequent text will tell what the reason is.

Apart from these two main communicative effects - to orient the reader towards the subsequent text and to backward-refer to a previously asked question -, 17 contains the presupposition that it is the case that health insurance companies make money on sick people. Depending on whether this can be assumed to be a previously accepted truth or not, this presupposition contributes to a certain manipulative potential of the wh-headline. Note that while wh-headlines consistently entail the factivity of their proposition, verbsecond wh-questions not necessarily do. A case in point are so-called police questions (Meibauer 1991), cf. the contrast in 19.

a. Mit wem Heinz M. kurz vor seinem Tod noch telefoniert hat 'Whom Heinz M. talked to on the phone shortly before his death' b. Mit wem hat Heinz M. kurz vor seinem Tod noch telefoniert? 'Whom did Heinz M. talk to on the phone shortly before his death?'

$19 \mathrm{a}$ raises the strong expectation that the accompanying text will tell us about the person, or will present us with a list of people, whom Heinz M. talked to on the phone shortly before his death. It is thus taken for granted that Heinz M. talked to somebody before his death. However, the police detective asking $19 \mathrm{~b}$ must be prepared to find out that Heinz M. did not talk to anybody on the phone shortly before his death; and this finding would not be pragmatically inconsistent with $19 \mathrm{~b}$.

Taken together, my hypothesis is that wh-headlines are meta-representative speech acts operating in two directions. They are both backward-referring to a question from previous discourse and forward-referring to the subsequent text. Furthermore, they consistently presuppose the factivity of their proposition. The illocutionary force thus outlined seems to be one that is especially wellsuited for a newspaper headline: In forward-referring to the accompanying text, the wh-headline fulfils a basic task of a newspaper headline, namely to direct the reader's attention to the news article. In backward-referring to a previously asked question, the headline fulfils a second basic task of a newspaper headline, namely to arouse the readers' interest. From this perspective, one 
can say that a wh-headline is a mediator between what readers want to know and what they can learn from the newspaper text.

Before I continue with the question how the functional potential of whheadlines is related to properties of the clause type, a brief remark as to other contexts in which wh-headlines occur is in order. As pointed out above, wh-headlines are not restricted to headlines in newspapers. Other contexts in which wh-headlines occur are catch lines on magazine covers, chapter headings in fiction as well as non-fiction, titles of books and films, captions, and marginalia. One may ask the question whether wh-headlines fulfill the same illocutionary function in all of these contexts. Generally, it can be assumed that in all of these contexts, the common function of the wh-headline is of a discourse-deictic nature, in that the wh-headline, induced by its specific syntactic properties (see Section 3), refers to a certain piece of discourse which may be represented in a textual or pictorial mode - that is related to the headline by local proximity or multimodal attachment (e.g., in the case of a film title printed on a DVD case). However, the different contexts also differ considerably with respect to a number of features, e.g., discourse level (the whole of a book, a chapter in a book, a paragraph in a chapter) or discourse type (e.g., fiction vs. non-fiction, textual vs. pictorial), which may lead to the development of more specific functions in specific contexts (e.g., mainly discourse structuring functions in marginalia vs. mainly attention-getting functions in catch lines on magazine covers). With regard to this potential functional diversification, the restriction of the present study to newspaper contexts as one of the main context types of wh-headlines is warranted. Further work must show whether the results of the present study can be generalized with respect to occurrences of wh-headlines at other discourse levels and in other discourse types.

I will argue in the following sections that it is not arbitrary that exactly this specific clause type has become conventionalized as a headline. Rather, I will show that the verb-final wh-clause has certain formal properties that make it especially well-suited for the illocutionary functions outlined above. However, as I will argue subsequently, the properties of the clause type alone do not suffice to fully explain the functional potential of wh-headlines. The second important factor are specific contextual requirements of the headline that have to be taken into account.

\section{How clause types are related to speech acts}

It is a standard assumption in the literature on the syntax-pragmatics interface that clause types are related in fundamental ways to speech acts. Searle (1969) regards clause types as a kind of illocutionary indicator. In subsequent work, e.g., Bierwisch (1980), Bach \& Harnish (1979), Sadock \& Zwicky (1985), this interrelation has been elaborated on, with the notion of sentence mood becoming a key notion to account for the sentence type-speech act relation 
(for a recent discussion, cf. Portner 2018). In the literature on German sentence types, the account of Altmann (1993) is widely accepted in which he takes it that sentence mood is a complex sign composed of a form type and a functional type, where a bundle of formal properties on the formal side corresponds to a certain speaker attitude and/or an illocutionary potential on the functional side. For example, a verb-second declarative clause corresponds to a belief attitude, which is compatible with assertive speech acts, while a verb-second wh-interrogative clause corresponds to the attitude of a desire to get to know something, which is compatible with questioning speech acts. While Altmann's approach can be said to be a "correspondence approach" (Reis 1999:200), or a constructionist approach avant la lettre (cf. Finkbeiner \& Meibauer 2016:2), another line of research into the sentence type-speech act interface is represented by compositional ("derivational") approaches that try to derive the ability of a sentence type to convey a certain illocutionary force from particular syntactic properties.

In particular, there is the standard assumption in compositional approaches to sentence types that the ability of a sentence to be used as an independent utterance with a certain illocutionary potential is bound to the movement of the finite verb to the C-position (V-to-C-movement, cf. Truckenbrodt 2004, 2006; Lohnstein 2000). This assumption can account for the observation that it is typically verb-second and verb-first sentences, so-called root sentences, that are used as independent utterances with their own illocutionary potential, while verb-final sentences typically are used as embedded sentences that do not convey an illocution on their own. However, it is clear that there exist also a number of verb-final clause types in German that carry illocutionary force. Within the domain of wh-clauses, there are, in particular, two types of independent verb-final types in German, namely verb-final reflective wh-questions (Truckenbrodt 2013b), cf. 20, and verb-final wh-exclamatives (d'Avis 2001), cf. 21.

Was Frauen (wohl/nur/bloß) für ihren Kinderwunsch tun? what women MP for their wish to have children do '(I wonder) what women do for their wish to have children' Was FRAUen (nicht alles) für ihren KINderwunsch tun! what women MP for their wish to have children do '(I am surprised about) what women do for their wish to have children'

By the utterance of 20, the speaker conveys that she poses to herself the question what women do for their wish to have children, thereby not expecting an answer from the addressee. By the utterance of 21, the speaker expresses that she is astonished or surprised about what women do for their wish to have children; this is the typical exclamative speaker attitude. The question then is how one can account for the ability of the verb-final types 20 and 21 
to carry illocutionary potential without abandoning the standard assumption. One line of argument is that the sentence types 20 and 21 display additional formal and prosodic features that contribute to their potential to carry illocutionary force (e.g., Altmann 1993). For reflective questions such as 20, it has been argued that the rising intonation [/], together with a near-obligatory modal particle that comes out of the set $\{$ wohl, nur, blo $\beta\}$ are the key features that are responsible for their specific illocutionary potential (Truckenbrodt 2013a). For 21, it can be argued that it is the specific exclamative stress pattern (indicated by capitalization) to which the expression of the specific exclamative speaker attitude must be connected (d'Avis 2001).

However, if we compare this to wh-headlines, we find that wh-headlines behave differently. As to their formal properties, wh-headlines share with 20 and 21 the final position of the finite verb and the occurrence of a wh-phrase in left-most position. However, while reflective questions such as 20 typically have rising intonation (indicated by [/]), wh-headlines must be realized, when read aloud ${ }^{5}$, with falling intonation (indicated by $[\backslash]$ ), cf. the contrast in $22 \mathrm{a}-\mathrm{b}$.
a. Was Frauen (wohl/nur/bloß) für ihren Kinderwunsch tun? [/]
'(I wonder) what women do for their wish to have children'
b. Was Frauen für ihren Kinderwunsch tun [ $\backslash]$
'What women do for their wish to have children'

Moreover, 22 indicates that while reflective questions typically display a modal particle of the set $\{$ wohl, nur, blo $\beta\}$, wh-headlines typically do not display any modal particles. In a subsample of my corpus, a collection of wh-headlines taken from commentaries and editorials, only two of a total of 2.098 whheadlines were exhibiting modal particles. ${ }^{6}$ Finally, whereas verb-final whexclamatives such as 21 exhibit the characteristic exclamative stress pattern, wh-headlines do not, cf. the contrast in $23 \mathrm{a}-\mathrm{b}$.
a. Was FRAUen für ihren KINderwunsch tun!
'(I am surprised) what women do for their wish to have children'
b. Was Frauen für ihren Kinderwunsch tun
'What women do for their wish to have children'

Thus, wh-headlines do not exhibit any additional formal features that would allow us to distinguish them, formally, from the dependent interrogative type of verb-final wh-clauses, cf. 24-25.

(24) Heinz fragt, was Frauen für ihren Kinderwunsch tun 'Heinz asks what women do for their wish to have children'

(25) Was Frauen für ihren Kinderwunsch tun

'What women do for their wish to have children' 
Note that it is not trivial that 25 is, semantically, an interrogative sentence. As the wh-headline does not occur with an embedding matrix verb, it is, in principle, ambiguous between a wh-interrogative and a (free) wh-relative. This ambiguity can be made explicit if one embeds 25 under an interrogativeembedding matrix verb such as ask, and a relative-embedding matrix verb such as like, respectively.

(26) Heinz fragt, was Frauen für ihren Kinderwunsch tun.

(interrogative clause)

'Heinz asks what women do for their wish to have children'

Heinz mag, was Frauen für ihren Kinderwunsch tun.

(free relative clause)

'Heinz likes what women do for their wish to have children'

However, we may employ tests (cf. Bausewein 1990) that indicate that whheadlines are indeed, semantically, interrogative sentences. First, as whinterrogatives, also wh-headlines allow for multiple wh-elements, whereas free relative clauses don't, cf. 28-30.

Heinz fragt, welche Versicherung was zahlt.

(interrogative)

'Heinz asks which insurance pays for what.

(free relative)

${ }^{\star}$ Heinz mag, welche Versicherung was zahlt.

'Heinz likes which insurance pays for what'

Welche Versicherung was zahlt ${ }^{7}$

(wh-headline)

'Which insurance pays for what'

Second, as wh-interrogatives, wh-headlines allow for the quantifier alles ('all'), whereas free relative clauses don't, cf. 31-33.

(31) Heinz fragt, worauf es bei der Weltmeisterschaft im Treppenlaufen so alles ankommt. (interrogative) Heinz asks on what it at the world championship in stair climbing so all depends

'Heinz asks what counts at the world championship in stair climbing'

${ }^{\star}$ Heinz mag, worauf es bei der Weltmeisterschaft im Treppenlaufen so alles ankommt.

(free relative)

Heinz likes on what it at the world championship in stair climbing so all depends

'Heinz likes what counts at the world championship in stair climbing'

(33) Worauf es bei der Weltmeisterschaft im Treppenlaufen so alles ankommt $^{8} \quad$ (wh-headline) on what it at the world championship in stair climbing so all depends 'What counts at the world championship in stair climbing' 
Taken together, it becomes clear that wh-headlines are verb-final whinterrogatives that differ, syntactically, from embedded wh-interrogatives in not being dependent on a matrix verb. As against reflective questions and wh-exclamatives, they do not exhibit any additional formal markers such as a special intonation contour or a restrictive selection of modal particles which could explain their ability to carry an illocution. Therefore, the strategy to derive the illocutionary force of wh-headlines from formal features alone will not work. In order to account for the assignment of illocutionary force to whheadlines, it is indispensable to also reflect on their contexts of use. In the following, I will argue that the illocutionary potential of wh-headlines can be derived from the interaction of formal properties of the clause type and contextual restrictions of the headline.

\section{Why wh-headlines communicate what they communicate}

Above, the illocutionary function of wh-headlines was characterized as a meta-representative act that is both backward-referring to previous discourse and forward-referring to the subsequent text. I will show now that the backward reference can be accounted for by an analogy with quotational uses of verb-final sentences, which share with wh-headlines verb-final order and intonation, and that the forward reference can be accounted for by the role of the wh-phrase in the context of a headline.

Starting with the backward-referring function, it is the specific configuration of verb-final position and falling intonation in wh-headlines that elicits an interpretation as quotational utterance. To show this in more detail, I will first look at the different possible configurations of verb position and intonation, assuming here a simplified dichotomy of falling $[\backslash]$ and rising [/] intonation (cf. Altmann 1993).

In the default case, a German verb-second wh-clause with rising intonation such as 34 a receives a questioning interpretation.
a. Was hat Steinmeier erreicht [/]
'What did Steinmeier achieve'
b. Was hat Steinmeier erreicht $[\backslash]$
'What did Steinmeier achieve'

As has been pointed out repeatedly in the literature (e.g. Altmann 1993), verb-second wh-clauses in German can be realized with either rising or falling intonation. Therefore, nothing changes if we realize the clause with falling intonation, and thus, also $34 \mathrm{~b}$ in the default case gets a questioning interpretation.

Next, also a verb-final wh-clause with rising intontation will normally get a questioning interpretation, cf. $35 \mathrm{a}$. 

a. Was Steinmeier erreicht hat [/]
'What Steinmeier has achieved'
b. Was Steinmeier erreicht hat [ $\backslash]$
'What Steinmeier has achieved'

35 a can be either the reflective question type mentioned earlier, in which the speaker asks herself a question, not expecting an answer from a potential addressee (the acceptability of this reading is enhanced if we insert a modal particle such as wohl). Alternatively, 35a may be interpreted as echo question, i.e. as a question of the speaker as to whether this is what someone else asked before ('Did you ask what Steinmeier has achieved?'; cf. also 18 above). In any case, $35 \mathrm{a}$ is a kind of question.

However, if we change the intonation of the verb-final clause to falling intonation, as in $35 \mathrm{~b}$, the questioning interpretation disappears. What we get instead is a quotational reading. This reading has been described for usages such as 36 (cf. Oppenrieder 1989, Truckenbrodt 2013a,b).
A: Wie verdienen Kassen an Kranken?
A: 'How do health insurance companies make money on sick people?'
B: Wie bitte?
B: 'Pardon me?'
C: Wie Kassen an Kranken verdienen.
C: 'How health insurance companies make money on sick people.'

The interpretation of $36 \mathrm{C}$ is that $\mathrm{C}$ is reminding $\mathrm{B}$ of the content of the previous question of $\mathrm{A}$. Importantly, $\mathrm{C}$ is not herself asking this question. Rather, what $\mathrm{C}$ conveys is something like 'I say that A asked how health insurance companies make money on sick people, thus an assertion about what somebody else asked. $^{9}$

At this point, the analogy between utterances such as $36 \mathrm{C}$ and whheadlines becomes apparent. Wh-headlines share all the formal features of quotational uses of wh-clauses such as $36 \mathrm{C}$. Therefore, a quotational reading for wh-headlines suggests itself. Arguably, in the context of a headline, there is no previous co-text in which a question would be manifest, as is the case in the example 36. However, the total formal overlap with the quotational use can be assumed to coerce the quotational reading also for the headline, resulting in an interpretation where the author reminds the readers of a question that is, if only latently or virtually, part of previous discourse. This interpretation is all the more likely in the context of a headline, whose primary task it is to arouse a readers' interest. What could be more interesting to a reader than a question that is part of the current news discourse, but that has not been answered yet?

I will now turn to the forward-referring function of wh-headlines. A crucial formal aspect of wh-headlines that contributes to the determination 
of the forward-referring function is the occurrence of a wh-phrase in the left periphery of the clause. According to a standard semantic analysis, the whphrase opens an alternative space, i.e. a set of possible answers (Hamblin 1973, Lohnstein 2013). A wh-headline thus is a sentence that semantically contains an open slot, a knowledge gap, that carries the requirement to be filled. Different kinds of wh-sentences come with different expectations as to who is supposed to fill the knowledge gap. For standard verb-second wh-questions, it is the addressee that is supposed to fill the knowledge gap. For wh-headlines, it's different.

The crucial point is that wh-headlines are restricted to the context of a headline. That is, they cannot be used independently outside of the context of a headline. While it is safe to say that, in principle, any German clause type i.e., imperative, declarative, or interrogative clauses - can be used as headline, wh-headlines are the only clause type in German that can only be used as a headline.

(37) Macht's noch einmal, Jungs!

'Do it again, guys!'

(38) Boateng muss gehen

'Boateng must leave.'

(39) Was essen unsere Stars im Trainingslager?

'What do our stars eat at the training camp?'

(40) Was unsere Stars im Trainingslager essen [ $\backslash]$

'What our stars eat at the training camp'

While 37-39 would make both fully acceptable headlines and fully acceptable utterances outside the context of a headline, 40 is not mandated as an acceptable, independent utterance outside the context of a headline. (The only exception being quotational usages of verb-final wh-clauses, see above.)

Crucially, as headlines, verb-final wh-clauses appear in text-initial sequential position. If there is an occurrence of a wh-phrase within a headline, in text-initial position, one may assume that this strongly invites a forward bridging inference to the effect that it is the propositions of the subsequent text that will fill the knowledge gap contained in the proposition of the headline. This inference, of course, is largely based on readers' cultural knowledge about typographic and textual conventions in headline-text configurations. If this is true, then the forward-referring function of wh-headlines can be said to be the result of an interaction between the semantics of wh-phrases and the conventionalized usage of the clause in a specific position within a conventionalized headline-text configuration.

Now, it is clear that wh-phrases are not a particular property of whheadlines, but occur in a number of different wh-clause types that might be used as headlines. The wh-phrase should contribute the same meaning aspect 
in all wh-clause types, and therefore, one might conclude that all wh-clause types should be equally well-suited as headlines. But the different wh-clauses types differ in important aspects, and crucially, they are not all equally wellsuited as headlines.

\author{
Was hat Steinmeier erreicht? [/] / [ $]$ \\ 'What has Steinmeier achieved?' \\ Was Steinmeier wohl erreicht hat? [/] \\ '(I wonder) what Steinmeier has achieved' \\ Was Steinmeier erreicht hat $[\backslash]$ \\ 'What Steinmeier has achieved'
}

The verb-second wh-question 41 conveys that there is a knowledge gap on the side of the speaker $\mathrm{S}$ and that $\mathrm{S}$ wants the addressee $\mathrm{A}$ to fill this knowledge gap. According to Truckenbrodt (2004, 2013a,b), both meaning components can be derived from the syntactic structure of the sentence. The component ' $\mathrm{S}$ wants to know something' is induced by an abstract + wh-feature (which has a visible correlate in the wh-phrase), the component 'from A' is induced by verb movement to the C-position (i.e., to the verb-second position).

The reflective question 42 also conveys that $S$ wants to know something, but it does not convey that $S$ wants A to provide the answer. This can be accounted for, in Truckenbrodt's account, by the fact that 42 does contain a +wh-feature in its syntactic structure, inducing the meaning component ' $\mathrm{S}$ wants to know something', but no $\mathrm{V}$-to-C-movement, so the meaning component 'from A' is not induced.

What about the wh-headline 43 ? Obviously, while 43 does convey that there is a knowledge gap, it neither conveys that this knowledge gap is on the side of $S$, nor that $S$ wants A to fill this knowledge gap. However, as 43 shares its syntactic features with 42 , one would expect that it also shares the interpretation of 42 . What is it that induces the deviant interpretation of 43 ?

On my account, we may explain this as follows. First, the fact that 43 does convey that there is a knowledge gap can be motivated by the occurrence of a + wh-feature. The fact that the knowledge gap is not on the side of the speaker, but on the side of the addressee, follows from my quotational analysis of whheadlines. With a quotation, a speaker does not refer to her own attitudes, but to the attitude(s) of the speaker of the original utterance (which is taken to be the addressee - the reader has asked this question before). The quotational interpretation thus shifts the epistemic attitude, the existence of a knowledge gap, to the addressee. It can be made explicit in the paraphrase 'I say that readers ask what/why/how .... In accordance with Truckenbrodt's prediction, 43 does not contain the meaning component 'from A', as there is no V-to-Cmovement. But as the wh-phrase occurs in a headline context, the forward bridging inference is invited that the text will fill the knowledge gap. 
Along these lines, the special 'headline affinity' of wh-headlines, compared to other kinds of wh-clauses, can be derived from an interaction between their specific structural properties and a pragmatic exploitation of their being bound to the sequential position of headlines.

In the following section, I would like to widen the perspective somewhat, asking the more general question whether wh-headlines can be seen as relevance optimizers for readers.

\section{Whether wh-headlines optimize relevance}

In the pragmatic literature on the communicative functions of newspaper headlines, it has been claimed repeatedly that relevance is a key concept in explaining the overall impact of newspaper headlines. Dor (2003: 696) puts forward the hypothesis that newspaper headlines are "relevance optimizers". He uses the term 'relevance' in the technical sense of Relevance Theory (Sperber/Wilson 1995, Carston 2002). In Relevance Theory, relevance is a meta-principle of human cognition, which states - in the Cognitive Principle of Relevance - that human cognitive processes are geared to achieving the greatest possible cognitive effect for the smallest processing effort, and - in the Communicative Principle of Relevance - that an utterance raises the expectation of optimal relevance in its addressees. Thus, the relevance of an utterance is the greater, the greater the ratio of its cognitive effects to the processing effort it requires.

Dor (2003: 705) applies the notion of relevance to headlines such that "a short and simple text, it [the headline] optimizes the relevance of the story by minimizing processing effort while making sure that a sufficient amount of contextual effects are deducible within the most appropriate context possible" (Dor 2003: 705). The most appropriate headline for a news item is then the one which optimizes the relevance of the story for the readers (Dor 2003: 707). This can be achieved, according to Dor, by ten different strategies; for example, a headline may be more appropriate than some other one because it is shorter; because it is clearer; because it is more interesting; because it is more informative; and so on. From the assumption that headlines are relevance optimizers, it follows that if a headline is optimally relevant, a reader who has finished reading a headline "has already received the optimal amount of relevance for its story" (Dor 2003: 718). Therefore, according to Dor, "the reader who decides to read the headline [...] and move on to the next headline, rather than delve into the story, makes a perfectly rational decision, and actually gets the best (informational) value for (cognitive) money possible" (Dor 2003: 718).

Similarly, Ifantidou (2009: 699) suggests that readers "select headlines guided by expectations of relevance". However, according to Ifantidou, the relevance of a headline cannot be determined by using "appropriacy lists" such as the one used by Dor (2003), because it is unclear, e.g., what 
status the suggested properties have, whether there is a single overarching property, or whether some properties have priority over others (Ifantidou 2009:700). Furthermore, Ifantidou argues against the mediating (between story and reader) status of headlines, claiming that in many cases, headlines are purposely read for the sake of a quick and loose news update, without referring to "the story" at all. Instead, the focus of Ifantidou (2009) is on the "reader-effectiveness" of headlines and the role of inferences in headline interpretation. The most reader-effective headline, according to Ifantidou, is a creative, underinformative headline that is contextually enriched via different kinds of pragmatic inferences.

Interestingly, although Dor's and Ifantidou's views on the relevance of headlines differ in important points, they both come to the conclusion that optimally relevant headlines are those that can be read as autonomous texts, i.e. instead of the story. In Ifantidou's view, headlines are "autonomous meaningful constructions and are (or should be) designed to be interpreted as such" (Ifantidou 2009: 702); in Dor's (2003:718) view, the best headline for the story is "not supposed to make the ordinary reader go on reading the story, but to make sure that the reader has indeed received the best 'deal' in reading the headline itself' (original emphasis).

While this may be true for headlines of a standard assertive format, e.g., John Kennedy Jr.'s body found (Dor 2003) or Kate's back in therapy (Ifantidou 2009), it seems that things are different with wh-headlines. As pointed out above, the main communicative purpose of a wh-headline is to direct the readers to the subsequent text, as well as to remind the readers of a question that is (virtually) present in previous discourse. The communicative functions of wh-headlines are to a large extent determined by their form. As the whheadline contains an open wh-slot, a reader cannot be supposed to achieve a sufficient amount of cognitive effects from reading only the wh-headline. As a forward- (and backward)-referring device, a wh-headline is not, at least not in the same way as a standard assertive headline, an autonomous text. Rather, it is to be seen as a text that is very closely entangled, not only because of its content, but also because of its linguistic form, with the text that it introduces.

A similar observation has been made by Blom \& Hansen (2015) for click baits. Click baits, as illustrated below in examples from the German MSN news site (see 44-45), are a certain kind of forward-referring headlines that primarily occur in online news media and that can be assumed to be used in order to generate clicks and reading activity for commercial reasons.

(44) Diese Stars haben die Model-Gene in der Familie ${ }^{10}$ these stars have the model genes in the family 'These stars have the model genes in the family'

(45) So überrascht GoT-Star seine Fans jedes Mal aufs Neue ${ }^{11}$ so surprises GoT star his fans each time anew 'This is how a GoT [game of thrones] star surprises his fans each time anew' 
The forward-referring potential of click baits is determined by their containing text-deictic or cataphoric expressions, e.g., demonstrative pronouns such as dies- ('this, these'), cf. 44, or adverbs such as so ('so'), cf. 45. According to Blom \& Hansen (2015: 96), and contra Dor (2003) and Ifantidou (2009), optimal relevance of a click bait headline can only be reached if the reader clicks on the headline and reads (parts of) the story, but not if she scans the headline and moves on to the next story straight away.

Similarities between click baits and wh-headlines can be found in the fact that both headline types contain linguistic expressions whose content must be determined in context, thus directing the reader to the accompanying text. However, there are also important differences between click baits and wh-headlines. Syntactically, click baits are verb-second declarative clauses that are associated with an own illocution for purely syntactic reasons, while wh-headlines are verb-final wh-clauses that only receive their interpretation as independent utterances in the context of a headline. While click baits contain indexicals that point to the subsequent text, wh-headlines contain wh-phrases that project an answer into the subsequent text. Because of their being interrogative clauses, wh-headlines also have a reflective component, which is absent in click baits. Thus, while 46 engages the reader in some kind of reflective activity, 47 doesn't.

Wie ein GoT-Star seine Fans jedes Mal aufs Neue überrascht 'How a GoT star surprises his fans each time anew'

So überrascht GoT-Star seine Fans jedes Mal aufs Neue

'This is how a GoT star surprises his fans each time anew'

Furthermore, while click baits are exclusively forward-referring, it has been argued in this paper that wh-headlines are both forward- and backwardreferring. The backward-referring reading of wh-headlines is evoked by structural means, i.e. their verb-final order in combination with falling intonation, which is reminiscent of quotational uses. As argued above, the backward-referring reading plays an important role for the ability of wh-headlines to arouse a reader's interest. While both click baits and whheadlines share the function of directing the attention to the subsequent text, wh-headlines have the additional appealing effect to act as if they pick up one of the reader's own questions. Because of their reflective potential and their specific reader-appeal, wh-headlines can be assumed to generate more cognitive effects compared to click baits.

This is not to say that click baits are not appealing to readers. Click baits may well arouse the reader's interest by specific techniques such as, e.g., directly addressing readers (e.g. So gelingt Ihr Garnelencurry mit Mango garantiert ${ }^{12}$ '[If you do it] like this, your shrimp curry with mango will succeed') or by choosing topics that can be expected to be of special interest to readers (e.g., 
Diese drei Dinge hassen Männer beim Küssen'13, 'These three things men hate while kissing'). What is special for wh-headlines, compared to click baits, is that their reader appeal is induced already at the structural level.

In how far is it then mandated to say that wh-headlines optimize relevance? As argued in this paper, wh-headlines achieve their special functional potential because of their backward- and forward-referring properties. Therefore, wh-headlines in fact are very good examples of what Dor (2003) sees as "mediators" between the reader and the story. Wh-headlines connect a reader's previous question to a news article which is expected to answer this question. That is, a wh-headline mediates in very specific ways, induced by its specific linguistic properties, between a reader's question and a textual answer. Because of this, one can expect that readers will reach a considerable amount of cognitive effects from wh-headlines, namely, answers to their questions. However, these cognitive effects can be reached only if readers accept the relatively high processing effort it will take to not only read the headline, but also the accompanying news article. Therefore, as click baits, also whheadlines will become maximally relevant only if readers also read (parts of) the accompanying text.

\section{Summary}

In this paper, I have argued that verb-final wh-clauses with falling intonation are particularly apt to be used as headlines because they accomplish two functions: They remind readers of an open question that is part of previous discourse, and they direct readers to the accompanying text that will provide an answer to this question. I have derived these functions from an interaction between formal properties of the clause type and contextual restrictions of the headline format. If headlines, more generally, can be said to optimize relevance for readers, the question arises whether also wh-headlines, with their specific functions, can be said to optimize relevance. I have suggested that wh-headlines may be assumed to generate more cognitive effects compared to click baits, because they carry reflective potential and act as if they refer to a genuine reader question. On the other hand, wh-headlines and click baits, as compared to standard assertive headlines, become maximally relevant only if readers also read (parts of) the accompanying text. More generally, it follows that different types of headlines must be evaluated differently as to their ability to optimize relevance. 


\section{Notes}

* This work was funded by the German Research Foundation (DFG), grant number FI-2297/1-1.

1 Newspaper headline, https://www.aftonbladet.se/nyheter/a/zLjgdO/hurman-botar-en-fanatiker, 25 April 2019.

2 Book title, https://www.rockwoolfonden.dk/publikationer/hvad-vi-ved-omudsatte-unge/, 10 April 2020. Thanks to Simon Uffe Borchmann for providing this example.

3 Catch line on a French magazine cover.

$4 \quad$ The account presented here is part of a larger project on wh-headlines in German that is currently carried out at Johannes Gutenberg-University Mainz, funded by the German Research Foundation (DFG).

5 It is clear that headlines are a phenomenon of written discourse. Nonetheless, every written text, and every headline, carries the potential to be read aloud. With respect to wh-headlines, experienced readers of German have the strong intuition that they must be recited with falling intonation.

$6 \quad$ Cf. the following examples: (i) Warum Warren Buffet hier vorerst wohl nicht investieren wird [why Warren Buffet here for now MP not invest will; 'Why Warren Buffet is likely not to invest here for the time being'] (Focus, 31 March 2019); (ii) Warum Sie auch künftig ruhig Ihre Wurst aus England mitbringen können [why you also henceforward MP your sausage from England PRT-bring can; 'Why you can bring your sausage from England also in the future'] (die tageszeitung, 5 March 2001). Interestingly, wohl belongs to the set of modal particles that are compatible with wh-questions, while ruhig belongs to the set of modal particles that are incompatible with wh-questions. The fact that question-compatible modal particles are possible follows from my quotational account, which states that a wh-headline behaves like a quote of a question that was raised in previous discourse. The fact that question-incompatible modal particles can occur is an argument in favor of my claim that wh-headlines do not have questioning illocution.

7 Sonntags-Zeitung (Tages-Anzeiger), 28 August 2005.

$8 \quad$ Frankfurter Rundschau, 20 February 2017.

$9 \quad$ As to the illocutionary differences between 36C and echo questions such as How health insurance companies make money on sick people?, cf. Section 2 above.

10 https://www.msn.com/de-de/unterhaltung/celebrity/diese-stars-haben-diemodel-gene-in-der-familie-\%e2\%80\%93-teil-1-2/vi-BBW6VPQ, 20 April 2019. https://www.msn.com/de-de/unterhaltung/tv/got-star-isaac-fans-sind\%c3\%bcberrascht-dass-er-laufen-kann/vi-BBW9ekR, 20 April 2019. Headline on MSN linked to a video showing how to make shrimp curry, https://www.msn.com/de-de/sport/soccer_videos/so-gelingt-ihr-garnelencurry-mit-mango-garantiert/vi-BBTVQoe, 22 February 2019. Headline on heute.at, https://www.heute.at/life/love/story/Diese-drei-Dingehassen-Maenner-beim-Kuessen-40232790, 6 October 2017. 


\section{References}

Altmann, Hans. 1987. Zur Problematik der Konstitution von Satzmodi als Formtypen. Satzmodus zwischen Grammatik und Pragmatik, ed. by Jörg Meibauer. (Linguistische Arbeiten 180). Tübingen: Niemeyer, 22-56.

Altmann, Hans. 1993. Satzmodus. Syntax. Ein internationales Handbuch zeitgenössischer Forschung, ed. by Joachim Jacobs; Arnim von Stechow; Wolfgang Sternefeld; and Theo Vennemann. Vol. 1. (Handbücher zur Sprach- und Kommunikationswissenschaft 9). Berlin: de Gruyter, 1006-29.

Bach, Kent; Robert M. Harnish. 1979. Linguistic communication and speech acts. Cambridge, MA: MIT Press.

Bausewein, Karin. 1990. Akkusativobjekt, Akkusativobjektsätze und Objektsprädikate im Deutschen. Untersuchungen zu ihrer Syntax und Semantik. (Linguistische Arbeiten 251). Tübingen: Niemeyer.

Bierwisch, Manfred. 1980. Semantic structure and illocutionary force. Speech act theory and pragmatics, ed. by John R. Searle; Manfred Bierwisch; and Ferenc Kiefer. (Synthese language library 10). Dordrecht: Kluwer, 1-35.

Blom, Jonas Nygaard; Kenneth Reinecke Hansen. 2015. Click bait: Forward-reference as lure in online news headlines. Journal of Pragmatics 76, 87-100.

Carston, Robyn. 2002. Thoughts and utterances. The pragmatics of explicit communication. Oxford: Blackwell.

d'Avis, Franz. 2001. Über ,w-Exklamativsätze im Deutschen. (Linguistische Arbeiten 429). Tübingen: Niemeyer.

Dor, Daniel. 2003. On newspaper headlines as relevance optimizers. Journal of Pragmatics 35 (5), 695-721.

Finkbeiner, Rita. 2018. Warum After Work Clubs in Berlin nicht funktionieren. Zur Lizensierung von w-Überschriften in deutschen Pressetexten. Non-canonical verb positioning in main clauses, ed. by Mailin Antomo and Sonja Müller. (Linguistische Berichte, Sonderheft 25). Hamburg: Buske, 21-46.

Finkbeiner, Rita; Jörg Meibauer. 2016. Satztyp und/oder Konstruktion? Satztypen und Konstruktionen, ed. by Rita Finkbeiner and Jörg Meibauer. (Linguistik - Impulse und Tendenzen 65). Berlin, Boston: de Gruyter, 1-22.

Hamblin, Charles L. 1973. Questions in Montague English. Foundations of Language 10 (1), 41-53.

Held, Gudrun. 2005. Magazine Covers - a multimodal pre-text genre. Folia Linguistica 39 (1-2), 174-96.

Ifantidou, Elly. 2009. Newspaper headlines and relevance: Ad hoc concepts in ad hoc contexts. Journal of Pragmatics 41 (4), 699-720.

Lai, Linda; Audun Farbrot. 2014. What makes you click? The effect of question headlines on readership in computer-mediated communication. Social Influence 9 (4), 289-99.

Lohnstein, Horst. 2000. Satzmodus - kompositionell. Zur Parametrisierung der Modusphrase im Deutschen. (Studia grammatica 49). Berlin: Akademie. 
Lohnstein, Horst. 2013. E- und W-Interrogativsätze. Satztypen des Deutschen, ed. by Jörg Meibauer; Hans Altmann; and Markus Steinbach. Berlin: de Gruyter, 51-83.

Luuko-Vinchenzo, Leila. 1988. Formen von Fragen und Funktionen von Fragesätzen. Eine deutsch-finnische kontrastive Studie unter besonderer Berücksichtigung der Intonation. (Linguistische Arbeiten 195). Tübingen: Niemeyer.

Mårdh, Ingrid. 1980. Headlinese. On the grammar of English front page headlines. (Lund studies in English 58). Lund: CWK Gleerup.

Meibauer, Jörg. 1991. Existenzimplikaturen bei rhetorischen w-Fragen. Fragesätze und Fragen, ed. by Marga Reis; Inger Rosengren. (Linguistische Arbeiten 257). Tübingen: Niemeyer, 223-42.

Moore, Sarah G.; David T. Neal; Gavan J. Fitzsimons; and Baba Shiv. 2012. Wolves in sheep's clothing: How and when hypothetical questions influence behavior. Organizational Behavior and Human Decision Processes 117 (1), 168-78.

Nielsen, Niels Møller. 2020. Expanding Searle's analysis of interrogative speech acts: A systematic classification based on preparatory conditions. In Scandinavian Studies in Language, 11(1), 7-19.

Oppenrieder, Wilhelm. 1989. Selbständige Verb-Letzt-Sätze: Ihr Platz im Satzmodussystem und ihre intonatorische Kennzeichnung. Zur Intonation von Modus und Fokus im Deutschen, ed. by Hans Altmann; Anton Batliner; and Wilhelm Oppenrieder. (Linguistische Arbeiten 234). Tübingen: Niemeyer, 163244.

Pafel, Jürgen. 2016. Satztyp und kommunikative Intention. Satztypen und Konstruktionen, ed. by Rita Finkbeiner; Jörg Meibauer. (Linguistik - Impulse \& Tendenzen 65). Berlin, Boston: de Gruyter, 406-32.

Portner, Paul. 2018. Mood. Oxford: Oxford University Press.

Reis, Marga. 1999. On sentence types in German. An enquiry into the relationship between grammar and pragmatics. Interdisciplinary Journal for Germanic Linguistics and Semiotic Analysis 4 (2), 195-236.

Searle, John R. 1969. Speech Acts: An Essay in the Philosophy of Language. Cambridge: Cambridge University Press.

Sadock, Jerrold M.; Arnold M. Zwicky. 1985. Speech act distinctions in syntax. Language typology and syntactic description, ed. by Timothy Shopen. Vol. 1. Cambridge: Cambridge University Press, 155-96.

Sandig, Barbara. 1971. Syntaktische Typologie der Schlagzeile. Möglichkeiten und Grenzen der Sprachökonomie im Zeitungsdeutsch. (Linguistische Reihe 6). München: Hueber.

Searle, John R. 1969. Speech acts. An essay in the philosophy of language. Cambridge: Cambridge University Press.

Sperber, Dan; Deirdre Wilson. 1995. Relevance: Communication and cognition. $2^{\text {nd }}$ ed. Oxford: Blackwell.

Stojanova-Jovčeva, Stanka. 1980. Selbständige wie-Sätze als stilistisches Mittel in der deutschen Sprache der Gegenwart. Deutsch als Fremdsprache 17 (1), 23-27. 
Truckenbrodt, Hubert. 2004. Zur Strukturbedeutung von Interrogativsätzen. Linguistische Berichte 199, 313-50.

Truckenbrodt, Hubert. 2006. On the semantic motivation of syntactic verb movement to $\mathrm{C}$ in German. Theoretical Linguistics 32 (3), 257-306.

Truckenbrodt, Hubert. 2013a. Satztyp, Prosodie und Intonation. Satztypen des Deutschen, ed. by Jörg Meibauer; Hans Altmann; and Markus Steinbach. Berlin: de Gruyter, 570-601.

Truckenbrodt, Hubert. 2013b. Selbständige Verbletzt-Sätze. Satztypen des Deutschen, ed. by Jörg Meibauer; Hans Altmann; and Markus Steinbach. Berlin: de Gruyter, 232-46.

Weuster, Edith. 1983. Nicht-eingebettete Satztypen mit Verb-Endstellung im Deutschen. Zur Wortstellungsproblematik im Deutschen, ed. by Klaus Olszok; Edith Weuster. (Studien zur deutschen Grammatik 20). Tübingen: Narr, 7-87.

Winkler, Edeltraud. 1989. Selbständig verwendete VE-Sätze. Ein Überblick. Studien zum Satzmodus III. (Linguistische Studien, Arbeitsberichte 193). Berlin: Akademie der Wissenschaften der DDR, Zentralinstitut für Sprachwissenschaft, 118-58. 